\title{
Variations in soil moisture content in a rangeland catchment
}

\author{
ROHIT SALVE AND BARBARA ALLEN-DIAZ
}

Authors are geological scientist, Earth Sciences Division, Lawrence Berkeley National Laboratory, I Cyclotron Road, Berkeley, Calif. 94720 and associate dean for research and extension at the Environmental, Science, Policy and Management, 101 Giannini Hall, University of California, Berkeley, Calif. 947203100. At the time of the research, the senior author was a Ph.D candidate, Department of Environmental, Science, Policy and Management, University of California, Berkeley, Calif.

\begin{abstract}
Soil water studies for California rangelands have focussed on near-surface hydrologic processes, limiting our understanding of spatial-temporal dynamics of the water regime below the root zone. Soil moisture content and potential were monitored for 16 months in 12 locations in an annual grass dominated 20 ha catchment. The data collected were analyzed by ANOVA to determine significant spatial and temporal differences in soil moisture. Further analysis identified variables that influenced the amount of moisture present at a particular subsurface location. It was determined that there were significant differences in the amount of soil moisture present along the vertical profile of each site and between sites. Soil texture, type of vegetation cover, and elevation were the significant variables that influenced the soil moisture status.
\end{abstract}

Key Words: California rangelands, subsurface hydrology

The circulation of water between ocean, atmosphere and land is called the hydrologic cycle (Freeze and Cherry 1979). Within the context of rangeland hydrology, the land-based portion of the cycle as it may be operative on an individual watershed is of primary importance. This component of the cycle enters the system through precipitation and exits as streamflow or evapotranspiration. Overland flow is generated when rainfall intensities exceed infiltration rates (Horton 1933). In situations where soils are heterogeneous, overland flow is observed in certain portions of the watershed. This describes the partial-area-contribution concept as presented by Betson (1964).

Seasonal changes in the land components of the hydrological cycle cause important variations in the surface and subsurface flow dynamics in rangeland catchments in California. Examination of surface and subsurface flow dynamics is one step towards better understanding vegetation composition, productivity and growing season dynamics, as well as potentially elucidating possible watershed pollution flow paths.

Subsurface flow has been observed to be a significant source of runoff in certain situations (Whipkey 1966, Dunne 1969, Hewlett and Nutter 1970). Hewlett and Hibbert (1963) showed the feasibility of such flow experimentally. The prime requirement is a shallow horizon of high permeability at the surface (Freeze and Cherry 1979). Dunne and Black (1970), working on an experimental watershed in Vermont, developed the concepts for the mecha-

Thanks to Dan Hawkes and 2 anonymous reviewers for review of this manuscript Manuscript accepted 8 May 2000.

\section{Resumen}

Los estudios del agua del suelo en los pastizales de California se han enfocado en los procesos hidrológicos cercanos a la superficie, limitando nuestro entendimiento de las dinámicas espaciotemporal del régimen del agua abajo de la zona de raíces. El contenido de humedad en el suelo y el potencial se monitorearon durante 16 meses en 12 sitos de un área de captación dominada por zacates anuales. Los datos colectados se analizaron por ANOVA para determinar diferencias significativas espacio-temporal de la humedad del suelo. Análisis adicionales identificaron variables que influyeron en la cantidad de humedad del subsuelo presente en un sitio particular. Se determinó que hubo diferencias significativas en la cantidad de humedad presente a lo largo del perfil vertical de cada sitio y entre sitios. La textura del suelo, tipo de cobertura de la vegetación y la elevación fueron variables significativas que influyeron en el estado de humedad del suelo

nisms of saturated overland flow. Here surface saturation was found to occur because of a rising water table, and ponding and overland flow occurred when no soil moisture storage was available. A comprehensive understanding of the hydrochemical response of catchments is limited because of the complexity of the hydrology.

Infiltration rates and sediment production on a rangeland have been assumed to integrate the complex interactions of soil and vegetation factors for use as indicators of hydrologic conditions (Thurow et al. 1986). Compaction of surface soil and the removal of plant cover have been identified as the major impacts of grazing on the hydrologic cycle. While these conclusions are common to a large body of literature concerned with the hydrology of rangelands (e.g. Thurow et al. 1986, Rauzi and Hanson 1986, Wood and Blackburn 1981a, 1981b), insights to the subsurface hydrology of these systems have not been investigated.

The objective of this study was to determine the influence of catchment features such as soil texture, topography, and vegetation on the seasonal changes in soil moisture content in a rangeland. This paper provides a description and results of a statistical analysis used to identify variables (i.e. soil texture, elevation, vegetation type, precipitation and evapotranspiration) significantly influencing the spatial and temporal dynamics of soil moisture in a California rangeland catchment.

\section{Methods}

The study site was a 20-hectare (ha) watershed located $10 \mathrm{~km}$ west of Walnut Creek, in Contra Costa County, California (37 $54^{\prime} \mathrm{N}, 122^{\circ} 03^{\prime} \mathrm{W}$ ) (Fig. 1). Changes in soil moisture content and 


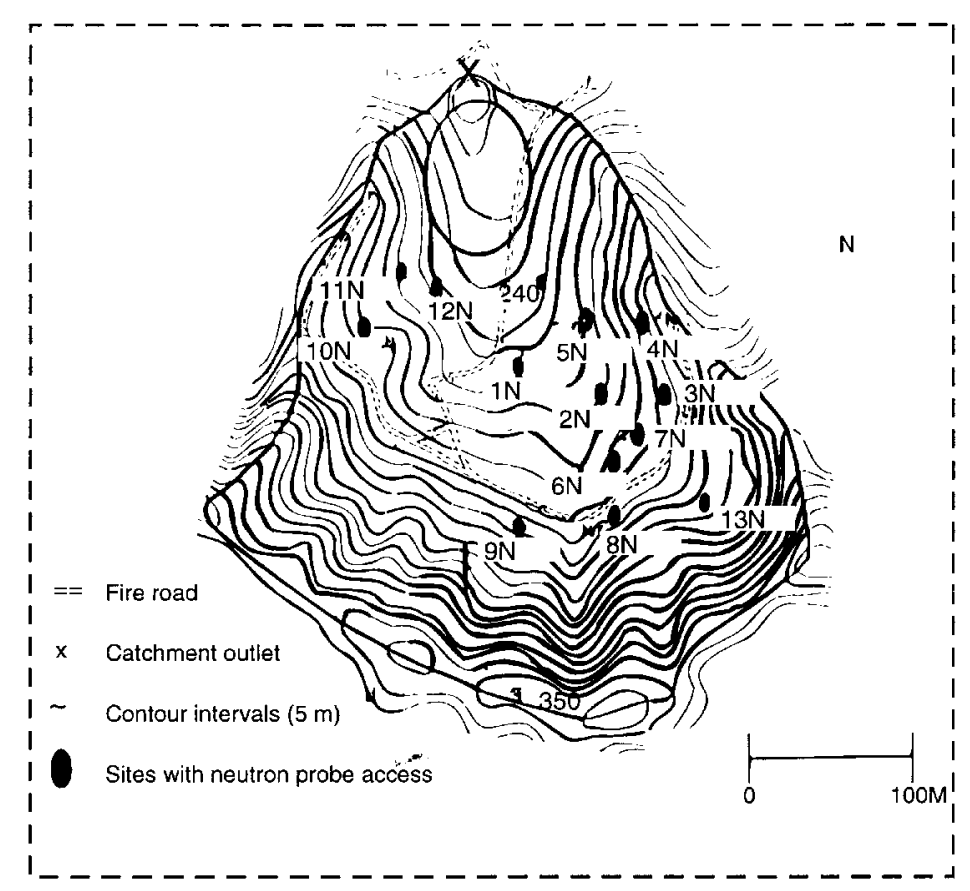

Fig. 1. Topographic map of Russell Tree Farm showing location of sites monitored for changes in soil moisture content.

matric potential were monitored along the vertical soil profile in 12 locations (Salve and Tokunaga 2000). These sites represented the 3 dominant vegetation types found in the catchment (annual grasses, shrubs, and trees) and 3 broad elevation categories (low, medium, and high) (Table 1).

Soil moisture content was determined by the neutron-probe method (Gardner 1986) and soil water potentials were determined using nested tensiometers. Soil removed during auguring of the 13 access holes for the neutron probe measurements, was collected in $0.15 \mathrm{~m}$ intervals and analyzed for soil particle size distribution. Soil moisture content was measured with a neutron probe at $0.15-\mathrm{m}$ intervals at monthly intervals while water potential were measured at weekly intervals during the wet period and monthly intervals late in the summer. Soil moisture content data were analyzed to determine significant spatial and temporal differences and to identify variables that influenced the amount of moisture present at a particular location within the catchment slopes.

\section{Results}

The study period started at the end of the 1992-93 rainfall season, a season in which precipitation totals for the region were greater than the average for the last * ReIative to catchment outlet amount of moisture (e.g. at Site $6 \mathrm{~N}$ the volumetric moisture content fell by $\sim 50 \%$ ), and in the ensuing months moisture losses from the profiles continued, but at decreasing rates. With the start of the winter rains, the amount of water in the soil profiles began increases during the first wet month (i.e. December 1993). In the next 2 months, when the bulk of the seasons' rain occurred, small increases were detected in all profiles, but these were much smaller than those observed early in the winter. Shortly after the wet season ended in early March 1994, the shallow profiles showed small losses in soil moisture content. The largest decreases were observed in April, and significantly smaller reductions occurred in the following months. This drying pattern was similar to that of the previous year, with the exception that the drying process in 1994 began almost 60 days earlier.

In the shallow soil profiles in all sites except $1 \mathrm{~N}$ and $10 \mathrm{~N}$ (Fig. 1), the deeper zones were wetter than the near-surface profile at any given time of year. In the case of $1 \mathrm{~N}$ and $10 \mathrm{~N}$ there was a period of 3 months coinciding with the wettest time of year when the shallow sections of the profiles recorded higher volumes of moisture than the deeper profiles. In each of the sites the total moisture lost from the near surface profile during the summer of 1993 was replenished during the following winter. Similar amounts of moisture were then lost from the profiles by the end of August, 1994. In essence, the shallow soil profiles (i.e. up to a depth of $\sim 1.0 \mathrm{~m}$ ) reached a fixed upper and lower limit in storing soil moisture towards the end of each season, irrespective of the amount of rainfall received for the 2 wet seasons.

The 5 deep monitored profiles $(6 \mathrm{~N}, 7 \mathrm{~N}$, $8 \mathrm{~N}, 9 \mathrm{~N}$, and $13 \mathrm{~N})$ ranged from 3.75 to $5.70 \mathrm{~m}$ in depth. Large losses in moisture following a wet winter (1992-93) in 4 of

Table 1. Physical features of monitored locations at the study site.

\begin{tabular}{lcccccc}
\hline \hline Site & Elevation $(\mathrm{m})^{*}$ & Aspect & Soil depth $(\mathrm{m})$ & Slope $(\%)$ & Vegetation & Soil texture \\
\hline $1 \mathrm{~N}$ & 14 & West & $>3.0$ & $<9$ & Grass & Sandy clay loam \\
$2 \mathrm{~N}$ & 33 & West & $\sim 2.5$ & $9-45$ & Grass/shrub & Clay loam \\
$3 \mathrm{~N}$ & 47 & West & $\sim 1.5$ & $>45$ & Grass & Loam-clay loam \\
$4 \mathrm{~N}$ & 51 & West & $\sim 1.5$ & $>45$ & Grass & Siltyclayloam \\
$5 \mathrm{~N}$ & 31 & West & $\sim 1.5$ & $9-45$ & Grass/shrub & Loam-.clay loam \\
$6 \mathrm{~N}$ & 46 & Northwest & $>6.0$ & $9-45$ & Grass/shrub & Sandy clay loam \\
$7 \mathrm{~N}$ & 48 & Northwest & $\sim 5.0$ & $9-45$ & Grass & Clay loam \\
$\mathrm{SN}$ & 50 & North & $\sim 5.0$ & $9-45$ & Tree & Sandy loam \\
$9 \mathrm{~N}$ & 47 & North & $\sim 5.0$ & $9-45$ & Tree/shrub & Sandy loam \\
$10 \mathrm{~N}$ & 42 & Northeast & $\sim 1.5$ & $>45$ & Tree/grass & Sandy learn \\
$11 \mathrm{~N}$ & 32 & East & $\sim 1.5$ & $9-45$ & Grass & Clay loam \\
$12 \mathrm{~N}$ & 9 & East & $\sim 5.0$ & $>45$ & Grass & Sandy loam \\
$13 \mathrm{~N}$ & 66 & Northeast & $\sim 5.0$ & $>45$ & Grass & Sandy loam \\
\hline
\end{tabular}

\# Because $12 \mathrm{~N}$ remained submerged during most ol the monitoring period it has not been included in the analysis 


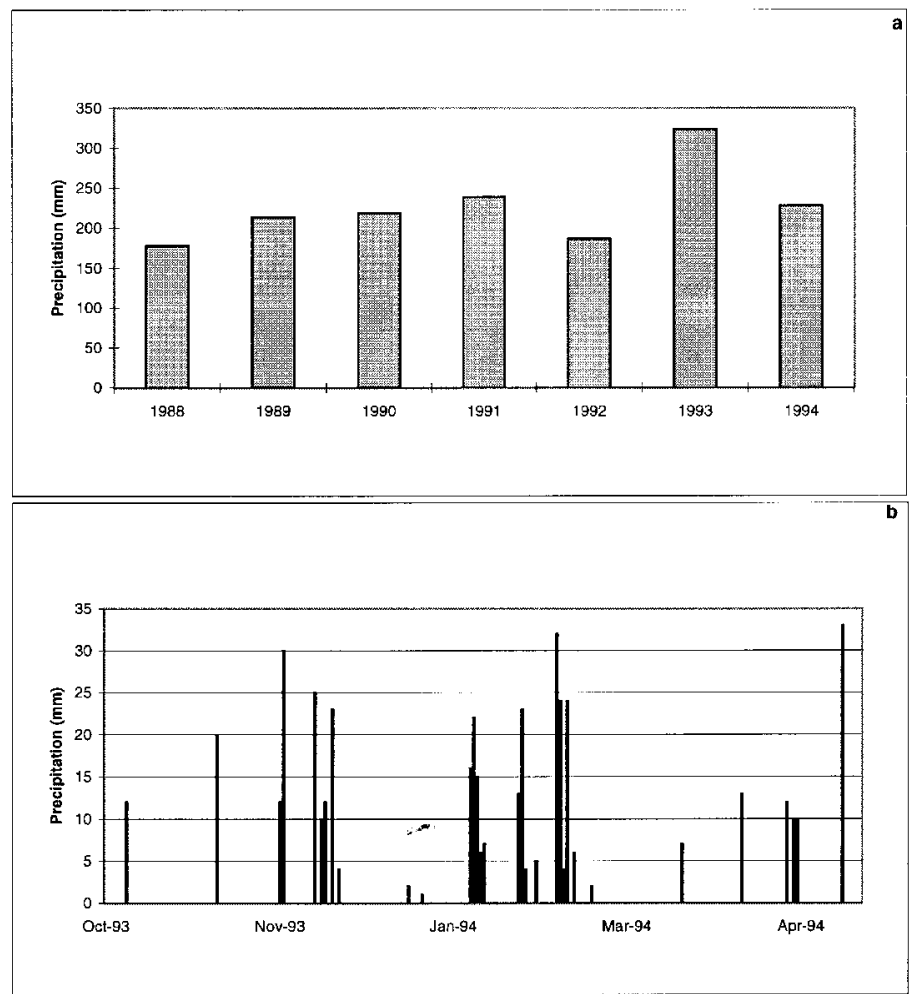

Fig. 2. (a) Annual totals of rainfall recorded at Walnut Creek located $10 \mathrm{~km}$ east of Russell Tree Farm. (b) Rainfall recorded at Russell Tree Farm.
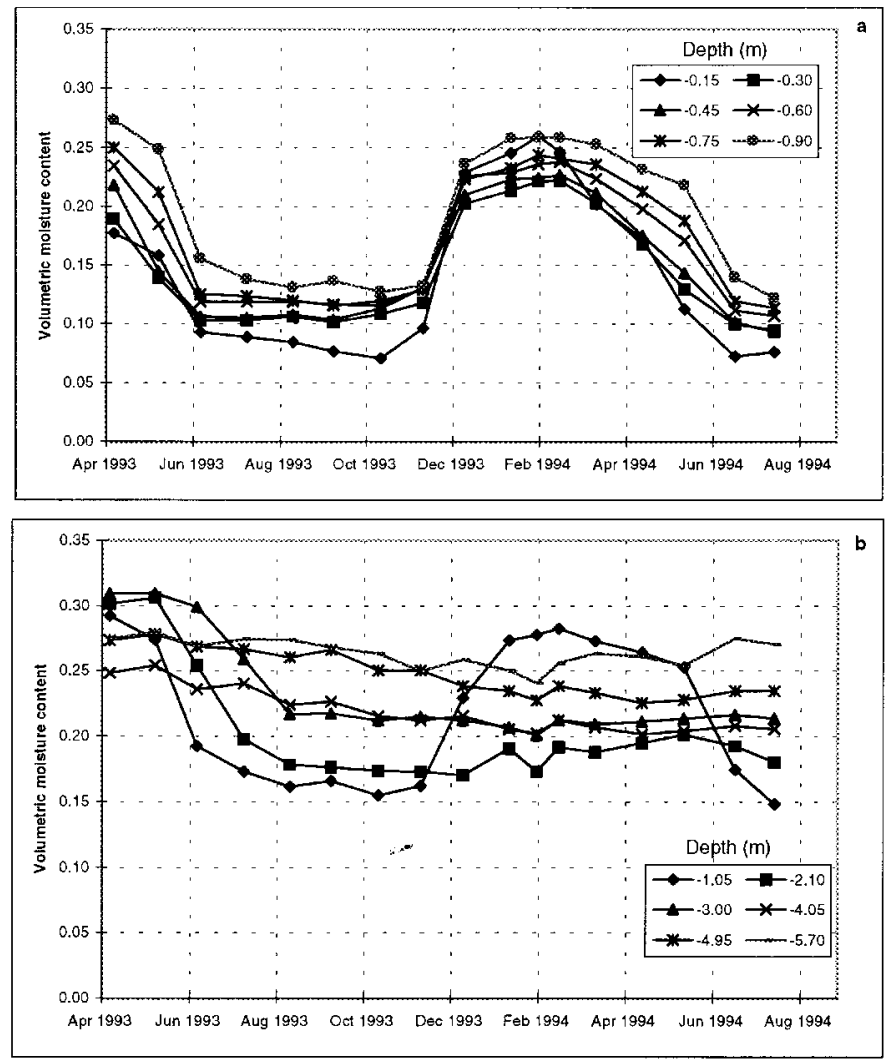

Fig. 3. Volumetric moisture content measured along the (a) shallow and (b) deep profile at site $6 \mathrm{~N}$. Similar measurements were made along the vertical profiles of all the monitored sites. the 5 sites extended beyond the $2.0 \mathrm{~m}$ depth. The single exception $(7 \mathrm{~N})$ recorded losses in moisture which were largely restricted to the top $1.9 \mathrm{~m}$ of the profile.

Among these sites, at depths greater than $2.0 \mathrm{~m}$, changes in soil moisture content varied considerably. Of the 5 deep locations, $7 \mathrm{~N}$ consistently contained most water per unit volume of soil, while $8 \mathrm{~N}$ was always the driest. Throughout the monitoring period the difference in wetness between these 2 sites also remained fairly constant. In the remaining deep sites the relative difference in wetness, however, continued to change at different times of year. Thus Site $13 \mathrm{~N}$ had an average moisture content similar to $8 \mathrm{~N}$ for the first 7 months of monitoring, but deviated for the remaining period as $8 \mathrm{~N}$ dried at a faster rate. Site $9 \mathrm{~N}$ initially recorded average moisture amounts similar to $7 \mathrm{~N}$, but dried significantly faster in the ensuing summer months. This difference continued to increase during the wet winter months, when $7 \mathrm{~N}$ retained much higher amounts of water. Site $6 \mathrm{~N}$, which was drier than $9 \mathrm{~N}$ in early May 1993, had similar rates of drying and wetting, and so maintained a near constant average difference in wetness as $9 \mathrm{~N}$.

In the deeper profiles moisture content tended to increase with depth. A single exception to this was $8 \mathrm{~N}$, where during the summer of 1993 the deepest zone in the profile was drier than the zones lying between 0.6 and $2.5 \mathrm{~m}$

\section{Data Analysis}

Neutron probe data collected monthly at $0.15 \mathrm{~m}$ intervals over a vertical distance of $1.05 \mathrm{~m}$ in 12 sites was analyzed by ANOVA (SPSS 1993) to determine if there were significant spatial and temporal differences in moisture content measured at different locations within the catchment. Specifically, 3 null hypotheses were tested:

Ho: Within a vertical soil profile (i.e. each site), mean moisture content (average of 16 months) does not vary significantly by depth.

Ho: Among the 12 sites, mean moisture content (average of 16 months) does not vary significantly by depth.

Ho: At each measured depth along the 12 vertical profiles, moisture content does not vary significantly in time.

All 3 hypotheses were rejected by the ANOVA tests. These tests established that at depths between 0.15 and $1.05 \mathrm{~m}$, the moisture content within the catchment changed significantly during the monitoring period. Further, these tests suggested that significant differences existed in the amount of moisture, both within 11 sites 
Table 2. Multiple regression models developed for 4 seasons and for entire monitoring period.

\begin{tabular}{lrc}
\hline \hline Variable & \multicolumn{1}{c}{$\mathrm{B}$} & \multicolumn{1}{c}{ SEB } \\
\hline Very wet season & $1.79 \mathrm{E}-03$ & $1.76 \mathrm{e}-04$ \\
Clay & $-7.25 \mathrm{E}-02$ & $7.56 \mathrm{E}-03$ \\
Distance & $-7.29 \mathrm{E}-04$ & $1.86 \mathrm{E}-04$ \\
Elevation & $-4.38 \mathrm{E}-02$ & $5.27 \mathrm{E}-03$ \\
Tree & $-4.38 \mathrm{E}-02$ & $5.27 \mathrm{E}-03$ \\
(Constant) & $1.88 \mathrm{E}-01$ & $1.10 \mathrm{E}-02$ \\
& & \\
Wet season & & \\
Clay & & \\
Distance & $1.36 \mathrm{E}-03$ & $2.47 \mathrm{E}-04$ \\
Elevation & $-5.98 \mathrm{E}-02$ & $1.06 \mathrm{E}-02$ \\
Tree & $-1.14 \mathrm{E}-03$ & $2.62 \mathrm{E}-04$ \\
(Constant) & $-3.94 \mathrm{E}-02$ & $7.42 \mathrm{E}-03$ \\
& $1.95 \mathrm{E}-01$ & $1.55 \mathrm{E}-02$
\end{tabular}

\begin{tabular}{cr} 
Beta & $\mathrm{T}$ \\
\hline $4.80 \mathrm{e}-01$ & 10.21 \\
$-4.46 \mathrm{E}-01$ & -9.59 \\
$-1.88 \mathrm{E}-01$ & -3.92 \\
$-3.93 \mathrm{E}-01$ & -8.30 \\
$-3.93 \mathrm{E}-01$ & -8.30 \\
$1.71 \mathrm{E}+01$ & 0.00
\end{tabular}

Sig T

\begin{tabular}{rr}
\multicolumn{2}{c}{ Adjusted $R 2$} \\
\\
$2.90 \mathrm{E}-01$ & 5.51 \\
$-2.93 \mathrm{E}-01$ & -5.62 \\
$-2.32 \mathrm{E}-01$ & -4.33 \\
$-2.82 \mathrm{E}-01$ & -5.30 \\
$1.26 \mathrm{E}+01$ & 0.00
\end{tabular}
Adjusted R2

3.28E-01

\section{Dry season}

Distance

Elevation

Clay

Grass

Sand

Tree

(Constant)

$\begin{array}{rr}1.21 \mathrm{E}-01 & 5.66 \mathrm{E}-03 \\ -1.58 \mathrm{E}-03 & 1.41 \mathrm{E}-04 \\ 1.02 \mathrm{E}-03 & 2.43 \mathrm{E}-04 \\ 1.04 \mathrm{E}-02 & 4.14 \mathrm{E}-03 \\ -3.34 \mathrm{E}-04 & 1.71 \mathrm{E}-04 \\ -1.41 \mathrm{E}-02 & 5.31 \mathrm{E}-03 \\ 1.56 \mathrm{E}-01 & 1.48 \mathrm{E}-02\end{array}$

$\begin{array}{rr}-5.82 \mathrm{E}-01 & -21.41 \\ -3.18 \mathrm{E}-01 & -11.24 \\ 2.12 \mathrm{E}-01 & 4.19 \\ 8.37 \mathrm{E}-02 & 2.51 \\ -1.02 \mathrm{E}-01 & -1.95 \\ -9.88 \mathrm{E}-02 & -2.66 \\ 1.05 \mathrm{E}+01 & 0.00\end{array}$

Adjusted R2

$6.43 E-01$

0
0.0001
0
0

$\begin{array}{lrr}\text { Very dry season } & & \\ \text { Clay } & 1.48 \mathrm{E}-03 & 1.54 \mathrm{E}-04 \\ \text { Distance } & -1.14 \mathrm{E}-01 & 6.62 \mathrm{E}-03 \\ \text { Elevation } & -1.70 \mathrm{E}-03 & 1.66 \mathrm{E}-04 \\ \text { Grass } & 1.04 \mathrm{E}-02 & 4.85 \mathrm{E}-03 \\ \text { Tree } & -2.53 \mathrm{E}-02 & 5.68 \mathrm{E}-03 \\ \text { (Constant) } & 1.31 \mathrm{E}-01 & 9.79 \mathrm{E}-03\end{array}$

Overall model

Distance

Elevation

Grass

Shrub

(Constant)

$\begin{array}{rr}-1.01 \mathrm{E}-01 & 4.39 \mathrm{E}-03 \\ -1.44 \mathrm{E}-03 & 1.10 \mathrm{E}-04 \\ 3.50 \mathrm{E}-02 & 3.23 \mathrm{E}-03 \\ 2.50 \mathrm{E}-02 & 3.76 \mathrm{E}-03 \\ 1.24 \mathrm{E}-01 & 7.29 \mathrm{E}-03\end{array}$

$4.39 \mathrm{E}-03$
$1.10 \mathrm{E}-04$
$3.23 \mathrm{E}-03$
$3.76 \mathrm{E}-03$
$7.29 \mathrm{E}-03$

$\begin{array}{rr}3.20 \mathrm{E}-01 & 9.61 \\ -5.66 \mathrm{E}-01 & -17.19 \\ -3.52 \mathrm{E}-01 & -10.21 \\ 8.68 \mathrm{E}-02 & 2.15 \\ -1.83 \mathrm{E}-01 & -4.45 \\ 1.34 \mathrm{E}+01 & 0.00 \\ & \text { Adjusted } R 2\end{array}$
$-4.66 \mathrm{E}-01$
$-2.77 \mathrm{E}-01$
$2.71 \mathrm{E}-01$
1.71E-01
1.70E+01
$-23.02$
$-13.05$
10.851
6.65
0.00

AdjustedR2

$B$ Partial Regression Coefficients Beta Beta Coefficients Calculated for Regression Coefficients $T$ T-Test

and between sites. For the single exception, i.e. Site 9 , significant differences in the average moisture content along the vertical profile were not detected.

\section{Model building}

Following the 1 factor ANOVA tests a repeated measures analysis of variance was employed to detect for both spatial and temporal effects, and also to test whether there was an interaction between the 2 factors. The independent variables within the catchment for which locationspecific data were collected included soil texture (Fig. 4), elevation, and vegetation type (Table 1). Climatic data (precipitation and estimates of evapotranspiration) were used from a weather station in Walnut Creek (Fig. 5).

Since the variables thought to influence the moisture content in the catchment belonged to 2 broad categories, (i.e. weather related data that varied from month to month and time independent data), an effort was made to develop 2 predictive models.

In each case, the general form of the model was:

$$
\begin{aligned}
& \theta_{\mathrm{i}}=\beta_{0}+\beta_{1} \mathrm{X}_{1 i}+\beta_{2} \mathrm{X}_{21}+ \\
& \ldots . . \mathrm{B}_{p} \mathrm{X}_{p i}+e_{i}
\end{aligned}
$$

Where $\theta_{\mathrm{i}}$ is the predicted moisture content at a given location. The notation $\mathrm{X}_{\mathrm{pi}}$ indicates the value of the $p$ th independent variable for case $i$. The $\beta$ terms are unknown parameters (partial regression coefficients). In the first model only time independent variables (i.e. soil texture, elevation, depth in soil profile and vegetation type)were considered while in the second model only time dependent variables (precipitation and evapotranspiration) were considered.
Model with Time-Independent Variables:

The important variables (not changing in time) that influenced the amount of moisture in the soil were isolated by first grouping the 1,328 observations of soil water content (12 sites, for 16 separate months, at 7 depths, with observations missing from a depth of $1.05 \mathrm{~m}$ at Site $3 \mathrm{~N}$ )

To formally define the membership of each groups the distribution of moisture along the profile of each site, at each time period, was defined by a cubic function (since this function most accurately described the soil moisture distribution along each profile). The coefficients of the cubic function were then used to define 4 clusters for each site over the 16-month period using the between-groups linkage method, in which the similarity matrix was computed using the Euclidean distance method. The clusters from all 12 sites were then plotted to determine if all sites showed similar seasonal boundaries (Fig. 6). Observations of soil moisture content were then analyzed to determine the dominant independent variables influencing the amount of moisture. In this analysis 5 linear regression models were developed. The first included all 1,328 observations while the remaining 4 included observations from each of the 4 "seasons" (very wet, wet, dry, and very dry in Figure 6).

In all 5 linear-regression models, the 3 independent variables, clay content, distance from surface, and elevation were found to significantly influence the amount of moisture present at a given location (Table 2). From the stepwise regression procedure used to develop the regression model for each season, the adjusted correlation coefficient (Adj. $\mathrm{R}^{2}$ ) was highest for the 2 extreme climatic conditions, i.e., the wettest period and the driest period. The lowest Adj. $\mathrm{R}^{2}$ values were detected in the period between the wet and dry seasons.

In the regression model developed for the very wet season, significant independent variables influencing the soil moisture content were clay content, trees, distance, and elevation. Of these, clay content had the highest positive correlation with moisture content followed by grass, silt content, and shrubs (Table 3). The largest negative correlations were with sand content, followed by distance, trees, and elevation. In this regression the final Adj. $\mathrm{R}^{2}$ was 0.64 . For the transient period between the wet season and the dry summer months, the significant variables influencing the moisture content in the soil were the same as those detected for the wet season. However, the absolute value of the 

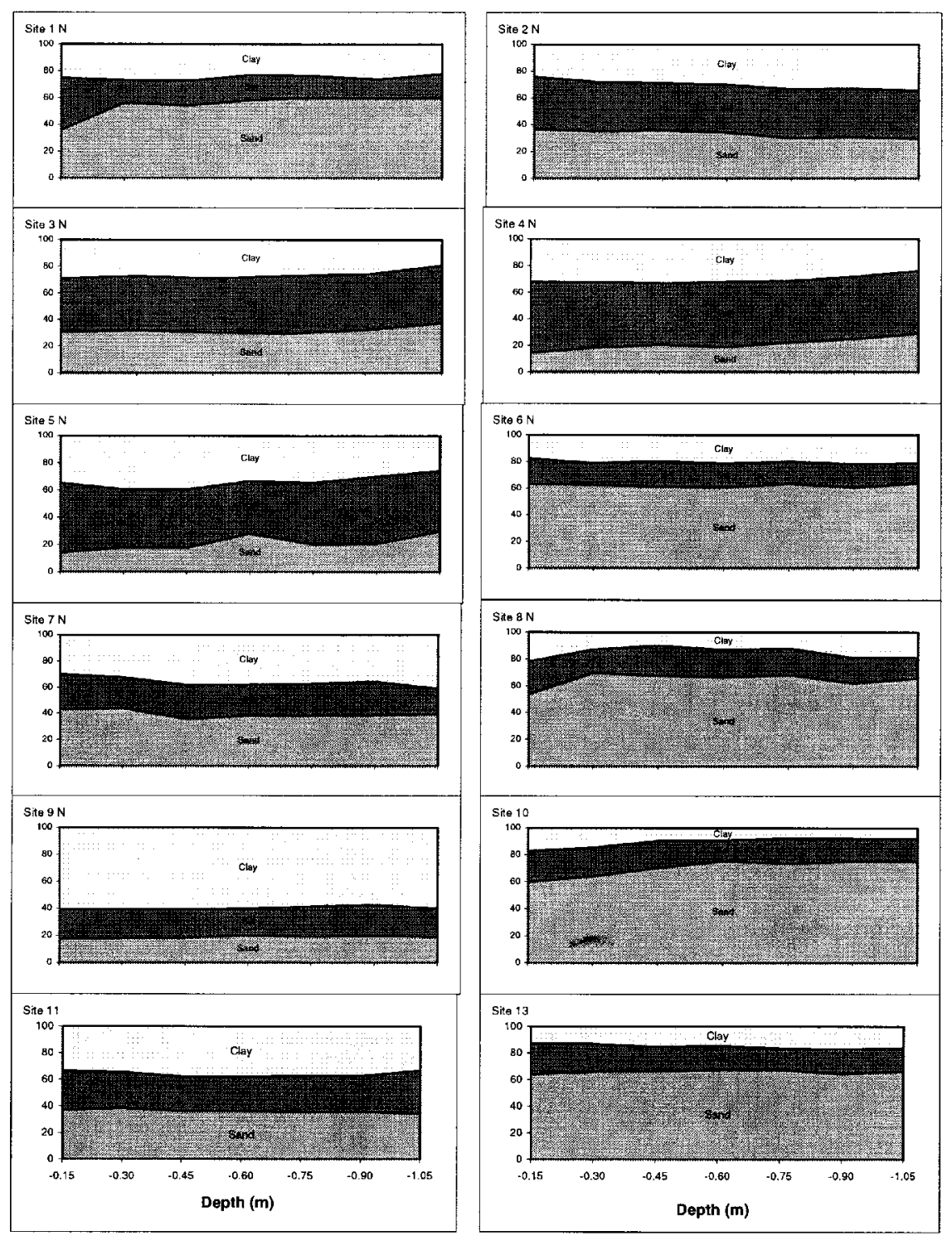

Fig. 4. Result of particle size analysis done on soils obtained from the vertical profile of the 12 monitored sites. The soil samples were collected at intervals of $0.15 \mathrm{~m}$. The ' $\mathrm{Y}$ ' axis in each plot indicated the percentage of sand, silt and clay present at each depth.

correlation coefficients for all of the independent variables (excluding trees) was reduced. Here, too, the final Adj. $\mathrm{R}^{2}$ was reduced to 0.32 .

In the regression equation developed from observations in the dry summer months, the independent variables significantly influencing the amount of moisture at a given location were clay, sand, distance, elevation, trees, and grasses. The final Adj. $\mathrm{R}^{2}$ was 0.58 . For the regression equation developed from observations in the driest summer months, the variables found to have significant influences on the amount of moisture content included clay, distance, elevation, grasses, and trees. For this equation the final Adj. ${ }^{2}$ was 0.64 .

For the regression analysis performed on observations made throughout the monitoring period, the variables significantly influencing moisture content were clay, grass, shrubs, distance, elevation, and distance. Here the Adj. $\mathrm{R}^{2}$ was reduced to 0.46 .

\section{Model with Time-Dependent Variables:}

The neutron-probe data collected at each site and depth in the catchment had the form of a typical time series. Since observations of moisture content at all depths indicated a sinusoidal pattern of changes over time the temporal components of the data were analyzed first. Here, an effort was made to build an autoregressive integrated moving average (ARIMA) model to explain the components of the series at each monitored depth. This model building procedure consists of 3 steps-identification, estimation and diagnosis (Box and Jenkins 1976). Identification of the model involved isolating the processes underlying the series by determining the 3 integers $\mathrm{p}, \mathrm{d}, \mathrm{q}$ in the ARIMA process generating series. Because the data were limited to 16 months of monitoring, parameters describing seasonal fluctuations were not included in the model building process. Since the identification process of the autoregressive and moving average components requires a stationary series (i.e., equal mean and variance throughout the series), all the times-series data was differenced twice and log-transformed to obtain a new stationary series. From the new series, the other ARIMA parameters $p$ and $q$ were developed from the autocorrelation function and partial autocorrelation func-

Table 3. Correlation coefficients between seasonal soil moisture content and independent variables.

\begin{tabular}{|c|c|c|c|c|c|c|c|c|c|c|c|c|c|}
\hline \multirow[b]{2}{*}{ Variable } & \multirow[b]{2}{*}{ Very wet } & \multicolumn{4}{|c|}{ Seasons } & \multicolumn{7}{|c|}{ Independent Variables } & \multirow[b]{2}{*}{ Tree } \\
\hline & & Wet & Dry & Very dry & Overall & Clay & Distance & Elevation & Grass & Sand & Shrub & Silt & \\
\hline Moisture & 1.00 & 1.00 & 1.00 & 1.00 & 1.00 & 0.49 & -0.43 & -0.33 & 0.28 & -0.45 & 0.09 & 0.19 & -0.42 \\
\hline Clay & 0.49 & 0.31 & -0.57 & 0.35 & 0.32 & 1.00 & 0.02 & -0.14 & -0.02 & -0.81 & 0.00 & 0.22 & 0.02 \\
\hline Distance & -0.43 & -0.28 & -0.38 & -0.56 & -0.46 & 0.02 & 1.00 & 0.00 & -0.02 & -0.09 & 0.03 & 0.13 & -0.01 \\
\hline Elevation & -0.33 & -0.33 & 0.32 & -0.43 & -0.35 & -0.14 & 0.00 & 1.00 & 0.05 & 0.15 & -0.24 & -0.09 & 0.19 \\
\hline Grass & 0.28 & 0.21 & 0.14 & 0.18 & 0.16 & -0.02 & -0.02 & 0.05 & 1.00 & -0.08 & -0.58 & 0.16 & -0.56 \\
\hline Sand & -0.45 & -0.32 & -0.30 & -0.33 & -0.30 & -0.81 & -0.09 & 0.15 & -0.08 & 1.00 & -0.14 & -0.75 & 0.24 \\
\hline Shrub & 0.09 & 0.11 & 0.08 & 0.07 & 0.07 & 0.00 & 0.03 & -0.24 & -0.58 & -0.14 & 1.00 & 0.24 & -0.36 \\
\hline Silt & 0.19 & 0.17 & 0.13 & 0.16 & 0.01 & 0.22 & 0.13 & -0.09 & 0.16 & -0.75 & 0.24 & 1.00 & -0.42 \\
\hline Tree & -0.42 & -0.32 & -0.22 & -0.29 & 0.14 & 0.02 & -0.01 & 0.19 & -0.56 & 0.24 & -0.35 & -0.42 & 1.00 \\
\hline
\end{tabular}



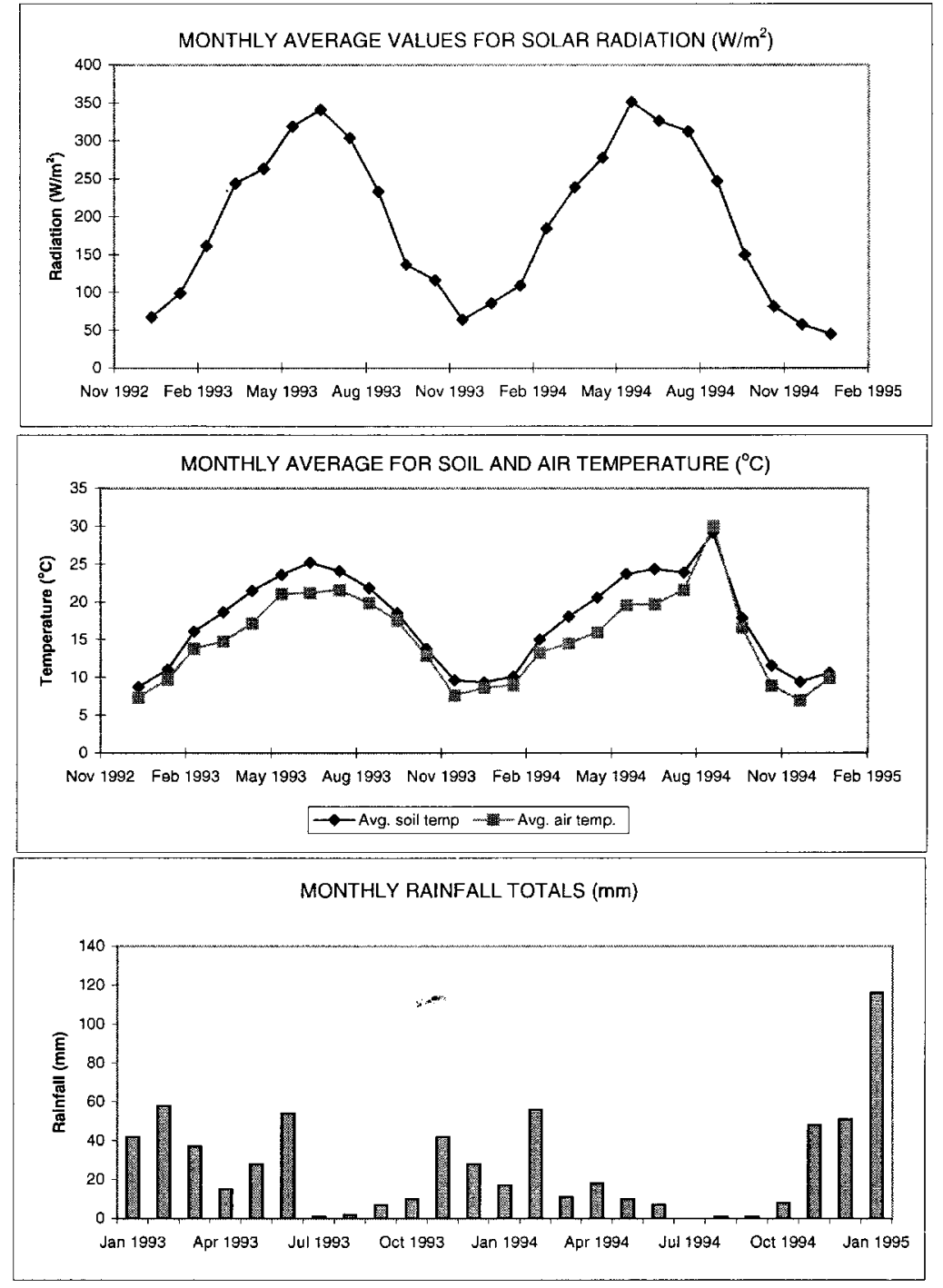

Fig. 5. Climatic data used to estimate evapotranspiration from a weather station at Walnut Creek located $10 \mathrm{~km}$ west of the study site.

tion. Coefficients of the ARIMA model for each series were then estimated using a statistical package (SPSS 1993), and tested to determine the maximum-likelihood coefficients. Finally, the autocorrelation function and partial autocorrelation function of the error series were checked to see if they were significantly different from 0.

Because robust ARIMA models could not be developed for each time-series, observations from 2 depths (i.e. 0.3 and $0.9 \mathrm{~m}$ ) from all 12 sites was differenced twice (to obtain a stationary series) and normalized as were the data of the 2 independent variables, monthly, rainfall and evapotranspiration (ET). With these normalized values, a regression analysis was done in which moisture content at a given site was regressed against the monthly rainfall and ET.

Results from the autoregression suggest that close to the surface (i.e. $0.15 \mathrm{~m}$ ), the regression model can account for very little of the moisture response in time using the autoregression parameter, rainfall, and ET (Table 4). At greater depths, the ARIMA model shows that the autoregressive component is able to significantly explain some of the seasonal variability. However, even though this model shows that moisture content is positively correlated with rainfall and negatively with ET, the contributions of these variables in improving the model are negligible.

\section{Discussion}

An important characteristic of the climate in the region is the tremendous variability in annual precipitation amounts (Fig. 4), which consequently results in a large variability in the amount of moisture penetrating into the soil. Evidence of this was apparent during the 16-month monitoring period, when the total rainfall recorded at the end of 1993-94 wet season was significantly lower than that observed

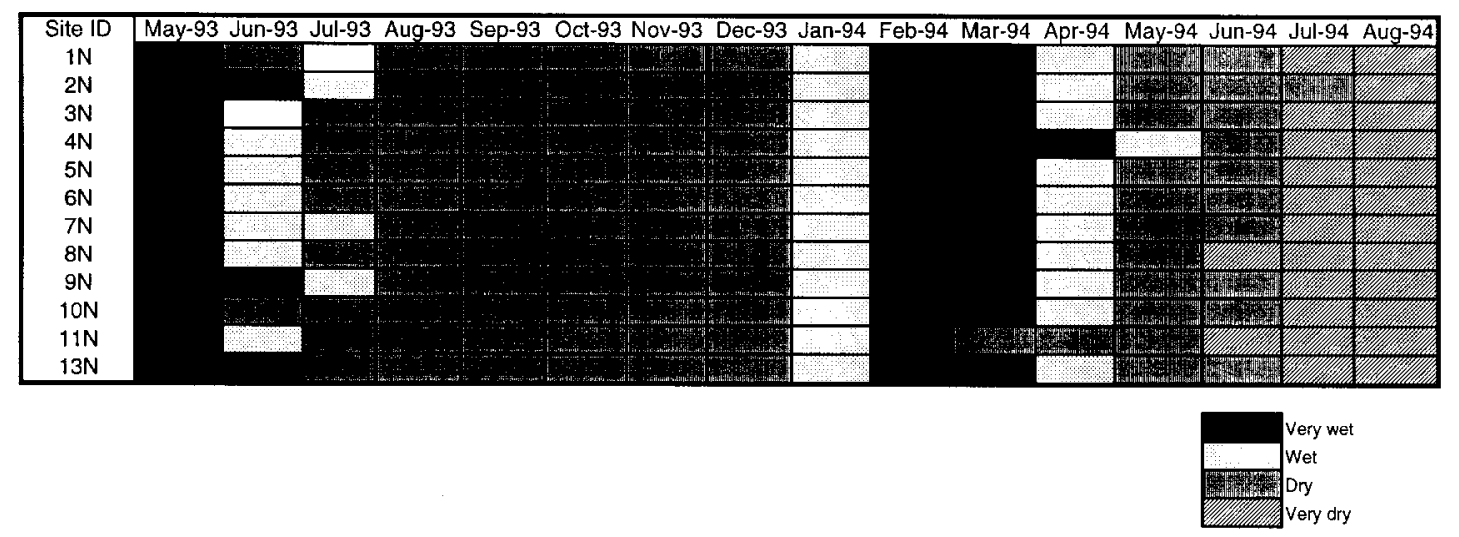

Fig. 6. Relative wetness at each site as determined by a clustering procedure. 
Table 4. Results of autoregression analysis of various depths in Site 11N.

\begin{tabular}{|c|c|c|c|c|}
\hline Variable & B & SEB & T-Ratio & Approx. Prob. \\
\hline \multicolumn{5}{|c|}{$\overline{\text { Depth }}=0.15 \mathrm{~m}$} \\
\hline AR1 & 7.17E-01 & $1.75 \mathrm{E}-01$ & 4.11 & $1.45 \mathrm{E}-03$ \\
\hline ET & $2.43 \mathrm{E}-04$ & $2.48 \mathrm{E}-03$ & 0.10 & $9.24 \mathrm{E}-01$ \\
\hline Rainfall & $1.09 \mathrm{E}-03$ & $2.38 \mathrm{E}-03$ & 0.46 & $6.54 \mathrm{E}-01$ \\
\hline Constant & $-2.04 \mathrm{E}+00$ & $4.14 \mathrm{E}-01$ & -4.94 & $3.44 \mathrm{E}-04$ \\
\hline \multicolumn{5}{|c|}{ Depth $=0.30 \mathrm{~m}$} \\
\hline AR1 & 7.44E-01 & $1.77 \mathrm{E}-01$ & 4.20 & $1.23 \mathrm{E}-03$ \\
\hline ET & $-1.11 \mathrm{E}-03$ & $1.24 \mathrm{E}-03$ & -0.90 & $3.88 \mathrm{E}-01$ \\
\hline Rainfall & $1.46 \mathrm{E}-04$ & $1.16 \mathrm{E}-03$ & 0.13 & $9.02 \mathrm{E}-01$ \\
\hline Constant & $-1.41 \mathrm{E}+00$ & $2.12 \mathrm{E}-01$ & -6.67 & $2.30 \mathrm{E}-05$ \\
\hline \multicolumn{5}{|c|}{ Depth $=0.45 \mathrm{~m}$} \\
\hline AR1 & 7.37E-01 & $1.78 \mathrm{E}-01$ & 4.14 & $1.37 \mathrm{E}-03$ \\
\hline ET & $-8.24 \mathrm{E}-04$ & $1.00 \mathrm{E}-03$ & -0.82 & 4.27E-01 \\
\hline Rainfall & $5.04 \mathrm{E}-05$ & $9.46 \mathrm{E}-04$ & 0.05 & $9.58 \mathrm{E}-01$ \\
\hline Constant & $-1.32 \mathrm{E}+00$ & $1.70 \mathrm{E}-01$ & -7.78 & $4.99 \mathrm{E}-06$ \\
\hline \multicolumn{5}{|c|}{ Depth $=0.60 \mathrm{~m}$} \\
\hline AR1 & $7.85 \mathrm{E}-01$ & $1.70 \mathrm{E}-01$ & 4.63 & $5.80 \mathrm{E}-04$ \\
\hline ET & $-3.71 \mathrm{E}-04$ & 8.89E-04 & -0.42 & $6.84 \mathrm{E}-01$ \\
\hline Rainfall & $5.71 \mathrm{E}-04$ & $8.11 \mathrm{E}-04$ & 0.70 & $4.95 \mathrm{E}-01$ \\
\hline Constant & $-1.30 \mathrm{E}+00$ & $1.61 \mathrm{E}-01$ & -8.12 & $3.24 \mathrm{E}-06$ \\
\hline \multicolumn{5}{|c|}{ Depth $=0.75 \mathrm{~m}$} \\
\hline AR1 & $7.55 \mathrm{E}-01$ & $1.86 \mathrm{E}-01$ & 4.07 & $1.58 \mathrm{E}-03$ \\
\hline ET & $-1.59 \mathrm{E}-04$ & $7.86 \mathrm{E}-04$ & -0.20 & 8.43E-01 \\
\hline Rainfall & $1.37 \mathrm{E}-04$ & 7.32E-04 & 0.19 & $8.55 \mathrm{E}-01$ \\
\hline Constant & $-1.27 \mathrm{E}+00$ & $1.36 \mathrm{E}-01$ & -9.28 & $8.00 \mathrm{E}-07$ \\
\hline \multicolumn{5}{|c|}{ Depth $=0.90 \mathrm{~m}$} \\
\hline AR1 & 7.76E-01 & $1.82 \mathrm{E}-01$ & 4.25 & $1.12 \mathrm{E}-03$ \\
\hline ET & $\S .22 \mathrm{E}-05$ & $7.49 \mathrm{E}-04$ & -0.08 & $9.35 \mathrm{E}-01$ \\
\hline Rainfall & $-6.80 \mathrm{E}-05$ & $6.88 \mathrm{E}-04$ & -0.10 & $9.23 \mathrm{E}-01$ \\
\hline Constant & $-1.25 \mathrm{E}+00$ & $1.34 \mathrm{E}-01$ & -9.34 & $7.40 \mathrm{E}-07$ \\
\hline \multicolumn{5}{|c|}{ Depth $=1.05 \mathrm{~m}$} \\
\hline AR1 & $7.73 \mathrm{E}-01$ & $1.74 \mathrm{E}-01$ & 4.44 & $8.00 \mathrm{E}-04$ \\
\hline ET & $-9.05 \mathrm{E}-05$ & 7.30E-04 & -0.12 & 9.03E-01 \\
\hline Rainfall & 4.34E-05 & $6.72 \mathrm{E}-04$ & 0.06 & $9.50 \mathrm{E}-01$ \\
\hline Constant & $-1.20 \mathrm{E}+00$ & $1.30 \mathrm{E}-01$ & 9.25 & $8.30 \mathrm{E}-07$ \\
\hline
\end{tabular}

during the previous winter. The depth to which soil was moistened was consequently much shallower in the winter of 1993-94, as is apparent in the significantly greater readings recorded in the deeper profiles in May 1993 than those recorded following the rains in February 1994 (Salve and Tokunaga 2000).

While precipitation was the single source of recharge to the catchment subsurface, results from the regression analysis indicate that soil texture, vegetation cover, and elevation had significant influences in the amount of moisture at a given location. From the regression models (Table 2) it is apparent that a strong seasonal influence caused periodic changes in the significance of these variables. For example, during the very wet season, clay greatly influenced the amount of moisture present in the soil. Over the following months, when the catchment continued to dry, the relative contributions of clay content in the predictive equations continued to decrease. Distance from the surface, however, was not as significant a factor during the wet period (when large amounts of water migrated into the pro- file) as it was in the summer months when the near-surface processes were able to reduce moisture amounts at rates faster than the deeper profiles.

The changes in moisture content in each profile represent a function of the moisture characteristic curves for each of the profiles. During the wet period, the amount of moisture retained in the soils is large, but as the matric potential in the soil decreases, there are initially significant amounts of drainage. With further decreases in soil moisture potentials, the amount of moisture lost per unit drop in pressure decreases, asymptotically approaching zero. During the wetting period, this behavior is reversed, with some differences resulting from hysteresis. moisture content with clay content can be explained by the general properties of clays to retain more moisture over a larger range of matric potentials than sands or silts. In the catchment where soil moisture in the near surface profile reached potentials below the functioning range of tensiometers $(<-8.0 \mathrm{~m})$ for a significant portion of the monitoring period, it can be
The significant positive correlation of assumed that soils with higher sand content had significantly lower moisture content. While this result is not unexpected, it is important to note that the regression analysis did not account for possible lenses of either sand or clay, which could significantly influence the amount of moisture migrating along the vertical plain.

The significant correlation of moisture content with depth (i.e., greater moisture content with increasing depth) can be explained by the vertical gradient in the intensity of near surface hydrologic processes like recharge and evapotranspiration (ET). Close to the surface, recharge and ET rates are the greatest, and with increasing depth the amount of moisture recharged or lost to ET decreases. Close to the surface, therefore, the net gain in the amount of water over a hydrologic year is close to zero, because all water received is recharged or lost to ET. At the same time, with increasing depth however, the net differences between recharge and moisture loss are smaller, resulting in greater storage of moisture over the year. It is only for brief periods following rainfall events that the near-surface profile has larger moisture content than the deeper profile. The higher correlation's observed in the drier seasons and lower correlation's observed in the wet period tend to support this argument.

The effect of vegetation cover on the moisture content as interpreted from the regression results indicates that there was a negative correlation of moisture content with tree cover, and a positive correlation with the presence of grasses. In most cases, no significant correlations between moisture content and shrubs could be observed. For areas characterized by large, yearly variability in rainfall, several reasons for this relationship between vegetation type and moisture content could exist. Perhaps the most significant of these is the year-round loss of soil moisture through transpiration from trees. Grasses, on the other hand, transpire over a relatively short period (between November and May), at a time when most of the season's precipitation is received. Besides removing water throughout the year, the tree cover is able to intercept larger amounts of the low-intensity rain than annual grasses. Grasses are also likely to prevent losses of moisture through surface evaporation by providing mulch of thick, matted biomass early in the summer.

The negative correlation of moisture content with elevation perhaps results from the combination of lateral drainage and lower infiltration occurring at the higher elevations. While no strong correla- 
tion between vegetation type and elevation among the monitored sites could be observed, in the higher elevations (above $300 \mathrm{~m}$ ) of the catchment, trees are the dominant vegetation type. Consequently, greater amounts of precipitation are intercepted in the higher elevations than in the lower areas of the catchment. Further, at the lower elevations, because of the topography of the catchment, subsurface flow paths converge, resulting in increasing amounts of flow passing through reducing areas. Therefore, at higher elevations less moisture travels through the soil.

\section{Summary}

Within a rangeland catchment in California, changes in moisture content in the soil profile followed an annual cycle, increasing in the winter following the start of the rains and decreasing during the dry summer months. The magnitude of these changes varied both along the vertical soil profile and at different locations within the catchment. Along the length of a soil column, fluctuations were the largest close to the surface and gradually decreased with depth. At depths greater than $3.0 \mathrm{~m}$, the seasonal changes in moisture content were small. Further, during seasons of low rainfall, the vertical migration of moisture was severely limited, resulting in little or no recharge in the deep profile.
The rainfall pattern (frequency, intensity, duration) of the semi-arid region influenced the extent to which recharge took place during a particular year. Infrequent rainfall events provided ample opportunity for evaporation losses at the surface, thereby reducing recharge to deep seepage.

The important parameters influencing the amount of moisture in the soil included seasonal rainfall, soil texture, vegetation type and elevation. Locations with annual grasses as the dominant vegetation cover retained the large amounts of moisture within the root zone, followed by shrubs and trees respectively. Soil moisture content was generally more in areas with higher clay content and decreased amounts of sand regardless of the vegetation cover. Soil moisture generally increased with depth along the vertical soil profiles.

\section{Literature Cited}

Box, G. E. P. and G. M. Jenkins. 1976. Time series analysis: Forecasting and control. Holden-Day, San Francisco, Calif.

Betson, R. P. 1964. What is watershed runoff? J. Geophys. Res., 69: 1541-1551.

Dunne, T. 1969. The significance of "partialarea" contributions to storm runoff for the study of sources of agricultural pollutants. Agr. Res. Ser., Danville, Vt.

Dunne, T. and R. D. Black. 1970. An experimental investigation of runoff production in permeable soils. Water Resour. Res., 6: 478-490.

Freeze, R. A. and J. A. Cherry. 1979. Groundwater. Prentice-Hall Inc., New Jersey.
Gardner, W. H. 1986. Water Content. In Methods of soil analysis, Part 1. Ed. A. Klute, Agronomy Monograph No. 9, $2^{\text {nd }}$ edition, Amer. Soc. Agron., Madison, Wisc.

Hewlett, J. D. and A. R. Hibbert. 1963. Moisture and energy conditions within a sloping soil mass during drainage. J. Geophys. Res., 69: 1081-1087.

Hewlett, J. D. and W. L. Nutter. 1970. The varying source area of streamflow from upland basins. Proceedings of the symposium on inter-disciplinary aspects of watershed management, Montana State University, Bozeman, Amer. Soc. Civil Eng., pp. 65-83.

Horton, R. E. 1933. The role of infiltration in the hydrologic cycle. Trans. Amer. Geophys. Union, 14: 446-460.

Rauzi, F. C. and C. L. Hanson. 1986. Water intake and runoff as affected by intensity of grazing. J. Range Manage., 19: 351-356.

Salve, R. and T. K. Tokunaga. 2000. Flows processes in a rangeland catchment in California. J. Range Manage. 53: 489-498.

SPSS for Windows, 1993. Release 6.1, SPSS Inc.

Thurow, T. L., W. H. Blackburn, and C. A. Taylor Jr. 1986. Hydrologic characteristics of vegetation types as affected by livestock grazing systems, Edwards Plateau, Texas. J. Range Manage., 39(6): 505-509.

Whipkey, R. Z. 1966. Subsurface stormflow from forested slopes. Bull. Internat. Assoc. Sci. Hydrology, 10(2): 74-85.

Wood, M. K. and W. H. Blackburn. 1981a. Sediment production as influenced by livestock grazing in the Texas Rolling Plain. J. Range Manage., 34: 228-231.

Wood, M. K. and W. H. Blackburn. 1981b. Grazing systems: their influence on infiltration rates in the Texas Rolling Plains. J. Range Manage., 34: 231-335. 